\title{
Metal Salts Assisted Enzyme-Based Extraction of Stevioside from the Leaves of Stevia rebaudiana Bertoni
}

\author{
A. Bhaskar Rao*\#, Sara A. George, Sateesh Alavala, H. M. Meshram, K. Chandra Shekar \\ Medicinal Chemistry and Pharmacology Division, CSIR-Indian Institute of Chemical Technology, \\ Hyderabad, India \\ Email: *adarirao2002@yahoo.co.in
}

Received 3 November 2015; accepted 21 December 2015; published 24 December 2015

Copyright @ 2015 by authors and Scientific Research Publishing Inc.

This work is licensed under the Creative Commons Attribution International License (CC BY). http://creativecommons.org/licenses/by/4.0/

c) (i) Open Access

\begin{abstract}
Stevioside, extracted from the leaves of Stevia rebaudiana Bertoni, is a natural, high intensity, lowcaloric sweetener with wide therapeutic activities. Conventional stevioside extraction methodologies involve the use of non-green solvents, supercritical fluids, microwaves, etc., however, all these processes are expensive, time-consuming and eco-unfriendly. Therefore an alternative process is desired for the isolation of stevioside. In this study, a novel enzyme-mediated extraction (EME) method has been developed. The dry stevia leaves were pre-treated with hydrolytic enzymes aided by transition metal salts $\left(\mathrm{FeCl}_{3}\right)$. This was followed by pressurized hot water extraction (PHWE) to release stevioside. The crude extract was purified and clarified through multi-stage membrane filtration. The results confirm that metal salt-assisted cellulase pre-treatment enhanced the yield of stevioside to $72 \%$, with $98 \%$ purity, which was higher in comparison to existing methods. Thus, the methodology developed establishes a simple, "green", enzyme-mediated process for the efficient isolation of stevioside under economical and eco-friendly conditions.
\end{abstract}

\section{Keywords}

Stevia rebaudiana, Enzyme-Based Extraction, Membrane Filtration, Stevioside, Natural Sweetener

\section{Introduction}

Sucrose has traditionally been the most commonly used sweetening agent in the food and beverage industries.

\footnotetext{
${ }^{*}$ Corresponding author.

"Indian patent No: 0175NF2015 dated July 2015.
}

How to cite this paper: Rao, A.B., George, S.A., Alavala, S., Meshram, H.M. and Shekar, K.C. (2015) Metal Salts Assisted Enzyme-Based Extraction of Stevioside from the Leaves of Stevia rebaudiana Bertoni. Advances in Bioscience and Biotechnology, 6, 734-743. http://dx.doi.org/10.4236/abb.2015.612075 
However, the consumption of high calorie sugars has resulted in various nutritional and clinical problems including obesity, type 2 diabetes mellitus and metabolic syndrome in humans [1]-[3]. Therefore, the food industry has witnessed a rise in demand, especially from diet-conscious people, for a natural, high intensity, low caloric, non-nutritive and stable sweetener that can be used as a sugar (sucrose) substitute in food and nutraceuticals.

Steviol-glycosides are natural diterpene glycosides present in the leaves of Stevia rebaudiana, which are 250 300 times sweeter than sucrose at a concentration of $0.4 \%(w / v)$, with low calorific value [4]. These steviolglycosides also possess wide therapeutic properties such as anti-diabetic, anti-cancer, anti-ulcer, antiviral and diuretic activities, thus enhancing their market value [5]-[8].

Although abundant literature on the isolation of stevioside using conventional solvent based extraction methods, microwaves, supercritical fluids, ultrasound, etc., is available, these methodologies have disadvantages such as use of non-green solvents, prolonged extraction time and requirement of multiple purification steps resulting in low yields. In addition, the processes generate noxious wastes and by-products which are toxic to health and the environment [9]-[13]. The potential wide spread use of the steviol-glycosides necessitates the development of a simple and effective extraction methodology, which has high efficiency and specificity, requires shorter time,lesser solvents and results in better yield and quality of the extracted compounds. Enzyme-based extraction of plant bioactives is a potential alternative to conventional solvent based extraction methodologies [14]-[23].

The objective of the present study is to design a state-of-the-art, metal salts-assisted enzymatic (EAE) process for the efficient extraction of stevioside from the leaves of Stevia rebaudiana, followed by a multi-stage filtration/purification step for the isolation of stevioside, with high yield and purity.

\section{Materials and Methods}

\subsection{Plant Material}

Stevia rebaudiana Bertoni leaves were obtained from Trisakthi farms, Hyderabad, India and confirmed taxonomically. Air-dried stevia leaves purchased from Sigma, USA (S5381) were used as a standard for comparison.

\subsection{Chemicals}

The laboratory, analytical and HPLC grade chemicals and solvents used in the study were purchased from Merck, India. The standard stevioside hydrate was procured from Sigma Chem. Co., USA. Cellulase (10 U/mg), hemicellulase (0.3 - $3 \mathrm{U} / \mathrm{mg}$ ) and pectinase (8 - $12 \mathrm{U} / \mathrm{mg})$ enzymes were bought from HiMedia Pvt. Ltd., Mumbai. Hollow fibre ultrafiltration (HF-UF) membrane $10 \mathrm{KDa}$ molecular weight cut off (MWCO) spiral wound module and NF membrane of hydrophilized polyamide (HPA) 250Da MWCO for membrane filtration were obtained from M/S Permionics Membranes India Ltd., Vadodara, India. Pyridine-D5 was bought from LGC Promochem Pvt. Ltd., Bengaluru.

\subsection{Analysis}

The purity of stevioside isolated from the crude stevia extract was quantified by HPLC (Gilson UK) and LCMS/MS (Shimadzu 2020 Lab Solutions) by using a Waters Spherisorb- $\mathrm{NH}_{2}$ column (C-18, $5 \mu \mathrm{m}, 220 \times 4.6 \mathrm{~mm}$ ), with isocratic solvent system acetonitrile and methanol $(85: 15)$ as the mobile phase, at a flow rate of $1 \mathrm{ml} / \mathrm{min}$.

The proton spectra for the stevioside were recorded on a 300MHz NMR Spectrophotometer (Bruker, Avance, Germany).

\subsection{Enzyme-Based Extraction of Stevioside}

The dried stevia leaf powder of 20 - 30 mesh was initially treated with hexane to remove plant waxes and leaf pigments. Later the leaf powder was filtered and pre-treated in aqueous phosphate buffer solution (pH 3 - 6) in the ratio of 1:5 - 1:30, containing hydrolytic enzymes: cellulase/hemicellulase/pectinase. The experiments were carried out in three sets: a) to the first set of experiments individual enzymes were added at different concentrations (1\% - 5\%); b) to the second set combinations of two enzymes were added; and c) in the third set, individual enzymes along with mineral salts like $\mathrm{FeCl}_{3} / \mathrm{CaCl}_{2}(0.05-1 \mathrm{M})$ were added. The reaction media were then incubated in a shaking incubator for 2 hours at $25^{\circ} \mathrm{C}-60^{\circ} \mathrm{C}$. After the enzymatic pre-treatment the aqueous ste- 
via extract was subjected to pressurized hot water extraction (PHWE) working under optimized operating conditions of $100 \mathrm{kPa}$ pressure, $90 \mathrm{rpm}$ and temperatures of $100^{\circ} \mathrm{C}-110^{\circ} \mathrm{C}$ for 10 minutes, for extraction of steviolglycosides. On completion of the extraction process, the crude extract was initially passed through a $63 \mu \mathrm{m}$ sieve, and the filtrate obtained was passed through an integrated membrane separation system, wherein the combined use of microfiltration (MF), ultrafiltration (UF) and nanofiltration (NF) was applied to recover stevioside of desired purity, as reported in our earlier studies [24] [25].

The yield and purity of the isolated stevioside were determined by HPLC and the structure of the stevioside was confirmed by ${ }^{1} \mathrm{H}-\mathrm{NMR}$ spectral data by comparing with standard stevioside.

\section{Results and Discussion}

Stevioside is the most abundant, sweet-tasting diterpene glycoside present in the leaves of Stevia rebaudiana, and has high commercial value as a natural, non-calorific alternative to sucrose in the food industry. The steviolglycosides isolated by conventional chemical or solvent based extraction processes however, leave a bitter after-taste after consumption; hence there is need to develop high yielding and environmentally friendly technologies which may assist in developing larger food based applications. In this study an improved methodology for the extraction and purification of stevioside was designed (Figure 1). The optimized process involves the initial removal of plant pigments and waxes by treating with non-polar solvent (hexane). After drying, the stevia leaves were enzymatically pre-treated in an aqueous phosphate buffer $\mathrm{pH} 4.6$ in the ratio of $1: 15$ with $1 \%$ of enzyme + $0.1 \mathrm{M} \mathrm{FeCl}_{3}$, at $55^{\circ} \mathrm{C}$ for 2 hours, followed by pressurized hot water extraction (PHWE).The filtered solution was passed through microfiltration using a micron cartridge ( $5 \mu \mathrm{m}$ pore size). Later, the MF permeate was fed to a spiral wound UF membrane module (10 kDa MWCO) operated at a feed pressure of $7 \mathrm{~kg} / \mathrm{cm}^{2}$ and temperature of $28^{\circ} \mathrm{C}$. The UF permeate was then fed to a series of five diafiltration (DF) units, for the further recovery of the stevioside and to remove leaf cell debris and other unknown impurities (Figure 2). The permeate from each diafiltration step was collected and processed using hydrophilized polyamide NF membrane (MWCO 250Da) at a feed pressure of $18 \mathrm{~kg} / \mathrm{cm}^{2}$ and temperature of $30^{\circ} \mathrm{C}$ until $80 \%-90 \%$ of water was removed to get concentrated stevioside solution. Thus the NF membrane process showed higher retention of stevioside from $80 \%$ 95\%. The crude stevioside-rich NF retentate was basified (to minimize the impurities—alkaloids, from the crude extract) and then extracted into the organic solvent (n-butanol), to isolate stevioside. The separated organic

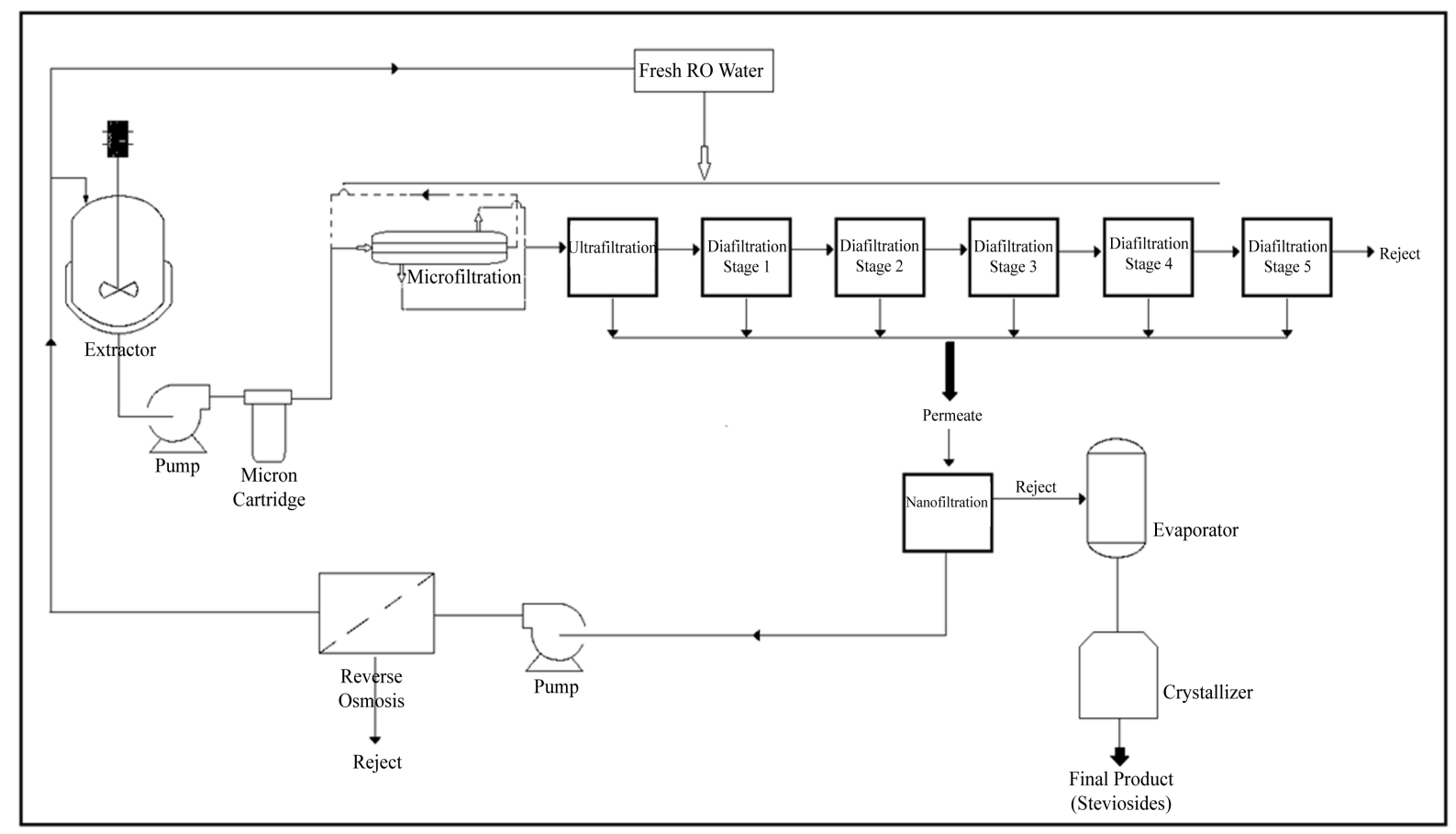

Figure 1. Schematic diagram for the isolation of stevioside. 


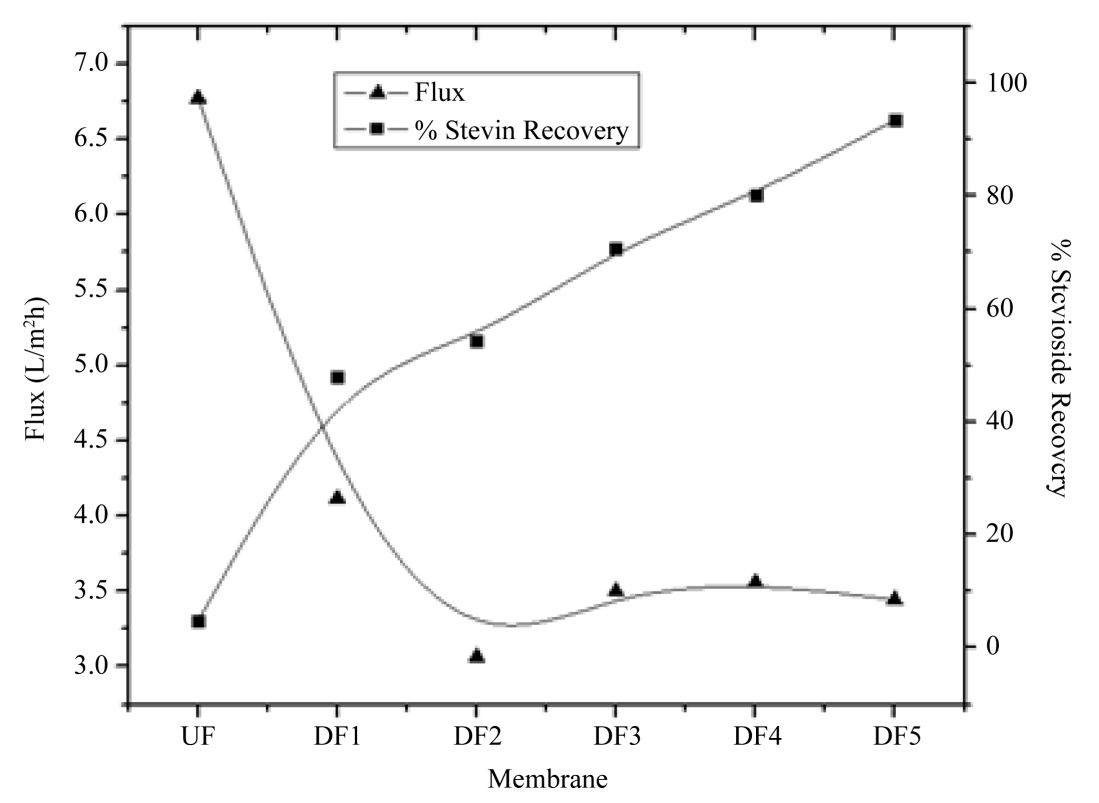

Figure 2. Variation of flux and \% steviosides recovery for UF-DF integrated membrane system.

layer was concentrated and crystallized with ethanol to obtain a yield of $72 \%$ of stevioside with $98 \%$ purity, in comparison to other known extraction methods (Figure 3). The structure of stevioside was confirmed by analytical data obtained by ${ }^{1} \mathrm{H}-\mathrm{NMR}$, Mass and IR spectroscopy, which were compared with literature values (Supplementary Figures 4-9).

A number of methods for the extraction of stevioside from stevia leaves are known, but all these techniques have several limitations. Supercritical $\mathrm{CO}_{2}$ extraction was employed to isolate steviosides to obtain a yield of $1.6 \%$ of steviol-glycosides; thus only $50 \%$ of stevioside was extracted [11]. This technique is applicable only to compounds that are $\mathrm{CO}_{2}$ soluble, thus despite being scalable it is inefficient in extracting the steviol-glycosides present in the stevia leaves and is also expensive. Ultrasonication of stevia leaves was performed for the extraction of steviosides, to obtain a yield of $43.62 \%$ of stevioside and $28.96 \%$ rebaudioside-A [26]. This technique is highly energy consuming, thus upscaling of the process would not be viable due to the large expenses involved. Microwave extraction of steviosides resulted in very low yields of stevioside (6.54\%) in 1 minute, and as in the case of ultrasonication, the process was costly, thus this technique cannot be used at the commercial scale [12].

Puri et al. (2012) [19] pre-treated the stevia leaves with cell wall degrading enzymes to isolate a mixture of steviol-glycosides ( $2.84 \mathrm{gm} / 100 \mathrm{gm}$ of stevia leaves). In our study, however, we were able to extract $98 \%$ pure stevioside at a yield of $72 \%$ (3.76 gm/100gm of stevia leaves) by using a combination of enzyme and transition metal (0.1 $\mathrm{M} \mathrm{FeCl}_{3}$ ), which synergistically enhanced the yields of stevioside in comparison to treatment with only cellulase. The hydrolytic enzymes have the ability to degrade or disrupt cell walls and membranes thus enabling the release of bioactives present in the stevia leaves, therefore enzyme-based extraction of bioactive compounds from plants is a potential alternative to conventional solvent-based extraction methods [27].

An integrated membrane extraction process was employed to isolate stevioside from the crude extract, making the process economical since the membranes are reusable and have high half-lives. This overall process developed can be scaled up and used for commercial purposes.

As the pressure mounts on the food industry to identify cleaner routes for the extraction of natural compounds; the methodology developed demonstrates the feasibility of enzymatic pre-treatment, followed by pressurized hot water extraction, in combination with inexpensive multi-stage membrane based separation process that helps in removing impurities and obnoxious residues present in the extract, thus improving the yields and taste profile of the stevioside isolated. This simple, efficient, cost-effective and eco-friendly process thus has great potential in the food industry.

\section{Conclusion}

In this study, the isolation of stevioside from Stevia rebaudiana leaves using enzyme-assisted extraction was 


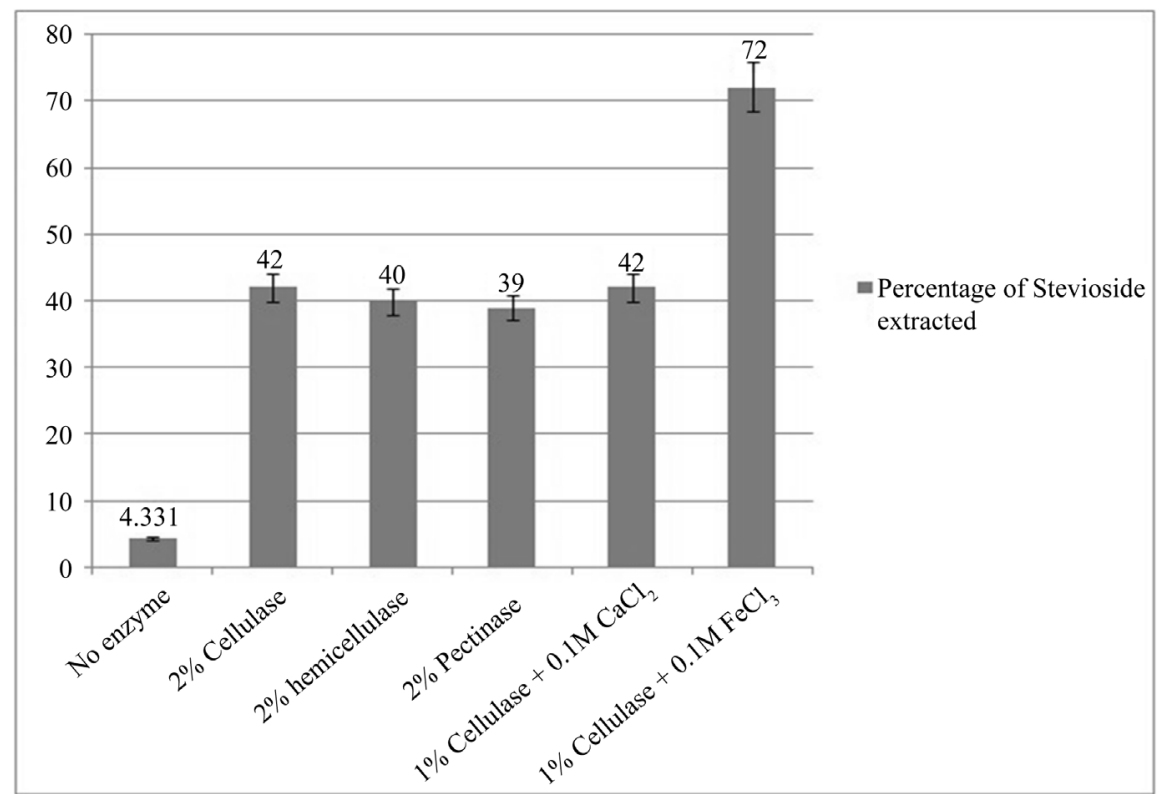

Figure 3. Effect of enzymes on the extraction of stevioside. The results given are the average of three experiments.

successfully demonstrated. From the results, it was confirmed that the combination of metal salt $\left(0.1 \mathrm{M} \mathrm{FeCl}_{3}\right)$ assisted enzymatic extraction with multi-stage membrane filtration (MF, UF and NF) enabled the enhancement of the isolated yields (72\%) and purity of stevioside from the stevia leaves. This process also helps in removing the undesirable alkaloids thus improving the organoleptic properties. Thus it is concluded that this green process of extraction of stevioside from stevia leaves, using cellulase assisted by metal salts, is more feasible in comparison to known conventional physical and chemical processes, since it is simple, economical and eco-friendly.

\section{Acknowledgements}

The authors would like to thank the Council of Scientific and Industrial Research (CSIR), New Delhi for funding this work under XII Five year plan project (CSC-0133). SAG sincerely thanks CSIR for awarding the Project fellowship.

\section{Conflict of Interest}

The authors do not declare any conflict of interest, whatsoever, either financially or otherwise.

\section{References}

[1] Yoo, S., Nicklas, T., Baranowski, T., Zakeri, I.F., Yang, S.J., Srinivasan, S.R. and Berenson, G.S. (2004) Comparison of Dietary Intakes Associated with Metabolic Syndrome Risk Factors in Young Adults: The Bogalusa Heart Study. American Journal of Clinical Nutrition, 80, 841-848.

[2] Anton, S.D., Martin, C.K., Han, H., Coulon, S., Cefalu, W.T., Geiselman, P., et al. (2010) Effects of Stevia, Aspartame, and Sucrose on Food Intake, Satiety, and Postprandial Glucose and Insulin Levels. Appetite, 55, 37-43. http://dx.doi.org/10.1016/j.appet.2010.03.009

[3] Basu, S., Yoffe, P., Hills, N. and Lustig, R.H. (2013) The Relationship of Sugar to Population-Level Diabetes Prevalence: An Econometric Analysis of Repeated Cross-Sectional Data. PLoS ONE, 8, Article ID: e57873. http://dx.doi.org/10.1371/journal.pone.0057873

[4] Geuns, J.M.C. (2003) Molecules of Interest: Stevioside. Phytochemistry, 64, 913-921. http://dx.doi.org/10.1016/S0031-9422(03)00426-6

[5] Takahashi, K., Matsuda, M., Ohashi, K., Taniguchi, K., Nakagomi, O., Abe, Y., et al. (2001) Analysis of Anti-Rotavirus Activity of Extract from Stevia rebaudiana. Antiviral Research, 49, 15-24. http://dx.doi.org/10.1016/S0166-3542(00)00134-0 
[6] Jayaraman, S., Manoharan, M.S. and Illanchezian, S. (2008) In-Vitro Antimicrobial and Antitumor Activities of Stevia rebaudiana (Asteraceae) Leaf Extracts. Tropical Journal of Pharmaceutical Research, 7, 1143-1149. http://dx.doi.org/10.4314/tjpr.v7i4.14700 http://www.bioline.org.br/pdf?pr08037

[7] Cekic, V., Vasovic, V., Jakovljevic, V., Mikov, M. and Sabo, A. (2011) Hypoglycaemic Action of Stevioside and a Barley and Brewer's Yeast Based Preparation in the Experimental Model on Mice. Bosnian Journal of Basic Medical Sciences, 11, 11-16.

[8] Paul, S., Sengupta, S., Bandyopadhyay, T.K. and Bhattacharyya, A. (2012) Stevioside Induced ROS-Mediated Apoptosis Through Mitochondrial Pathway in Human Breast Cancer Cell Line MCF-7. Nutrition and Cancer, 64, 10871094. http://dx.doi.org/10.1080/01635581.2012.712735

[9] Kutowy, O., Zhang, Q.S. and Kumar, A. (1999) Extraction of Sweet Compounds from Stevia rebaudiana Bertoni. US Patent No. 5972120.

[10] Moraes, E. and Machado, N.R. (2001) Clarification of Stevia rebaudiana (Bert.) Bertoni Extract by Adsorption in Modified Zeolites. Acta Scientiarum, 23, 1375-1380. http://periodicos.uem.br/ojs/index.php/ActaSciTechnol/article/viewFile/2779/1830

[11] Yoda, S.K., Marqes, M.O.M., Petentate, A.J. and Meireles, M.A.A. (2003) Supercritical Fluid Extraction from Stevia rebaudiana Bertoni Using $\mathrm{CO}_{2}$ and $\mathrm{CO}_{2}+$ Water: Extraction Kinetics and Identification of Extracted Components. Journal of Food Engineering, 57, 125-134. http://dx.doi.org/10.1016/S0260-8774(02)00281-9

[12] Jaitak, V., Badna, B.S. and Kaul, V.K. (2009) An Efficient Microwave-Assisted Extraction Process of Stevioside and Rebaudioside-A from Stevia rebaudiana (Bertoni). Phytochemical Analysis, 20, 240-245. http://dx.doi.org/10.1002/pca.1120

[13] Abelyan, V.H., Ghochikyan, V.T., Markosyan, A.A., Adamyan, M.O. and Abelyan, L.A. (2010) Extraction Separation and Modification of Sweet Glycosides from Stevia rebaudiana Plant. US Patent No. 7838044 B2.

[14] Delgado-Vargas, F. and Paredes-Lopez, O. (1997) Effects of Enzymatic Treatments on Carotenoid Extraction from Marigold Flowers (Tagetes erecta). Food Chemistry, 58, 255-258. http://dx.doi.org/10.1016/S0308-8146(96)00163-X

[15] Santamaria, R.I., Reyes-Duarte, M.D., Barzana, E., Fernando, D., Gama, F.M., Mota, M., et al. (2000) Selective Enzyme Mediated Extraction of Capsaicinoids and Carotenoids from Chili Guajillo puya (Capsicum annuum L.) Using Ethanol as Solvent. Journal of Agricultural and Food Chemistry, 48, 3063-3067. http://dx.doi.org/10.1021/jf991242p

[16] Ruiz-Teran, F., Perez-Amador, I. and Lopez-Munguia, A. (2001) Enzymatic Extraction and Transformation of GlucoVanillin to Vanilla Pods. Journal of Agricultural and Food Chemistry, 49, 5207-5209. http://dx.doi.org/10.1021/jf010723h

[17] Liu, L., Sun, J., Li, M., Wang, S., Pei, H. and Zhang, J. (2009) Enhanced Enzymatic Hydrolysis and Structural Features of Corn Stover by $\mathrm{FeCl}_{3}$ Pretreatment. Bioresource Technology, 100, 5853-5858. http://dx.doi.org/10.1016/j.biortech.2009.06.040

[18] Yadav, S. and Kumar, A. (2012) Enzymatic Extraction of Curcumin from Curcuma longa Rhizome. American Journal of PharmTech Research, 2, 898-905. http://www.ajptr.com/archive/volume-2/december-2012-issue-6/article-517.html

[19] Puri, M., Sharma, D., Barrow, C.J. and Tiwary, A.K. (2012) Optimisation of Novel Method for the Extraction of Steviosides from Stevia rebaudiana Leaves. Food Chemistry, 132, 1113-1120. http://dx.doi.org/10.1016/j.foodchem.2011.11.063

[20] Wang, W., Yuan, T.Q. and Cui, B.K. (2013) Fungal Treatment Followed by $\mathrm{FeCl}_{3}$ Treatment to Enhance Enzymatic Hydrolysis of Poplar Wood for High Sugar Yields. Biotechnology Letters, 35, 2061-2067. http://dx.doi.org/10.1007/s10529-013-1306-3

[21] Shen, Z., Jin, C., Pei, H., Shi, J., Liu, L. and Sun, J. (2014) Pretreatment of Corn Stover with Acidic Electrolyzed Water and $\mathrm{FeCl}_{3}$ Leads to Enhanced Enzymatic Hydrolysis. Cellulose, 21, 3383-3394. http://dx.doi.org/10.1007/s10570-014-0353-9

[22] Zhang, Y., Mo, L., Chen, F., Lu, M., Dong, W., Wang, Q., et al. (2014) Optimized Production of Vanillin from Green Vanilla Pods by Enzyme-Assisted Extraction Combined with Pre-Freezing and Thawing. Molecules, 19, 2181-2198. http://dx.doi.org/10.3390/molecules19022181

[23] Zhang, Y.D., Li, W., Lu, T. and Xia, Y.M. (2015) The Effect of Microwave Irradiation on Transglycosylation Pathway of Stevioside with Starches or Cyclodextrins Catalyzed by a Cyclodextrin Glucanotransferase. Journal of Molecular Catalysis B: Enzymatic, 120, 151-157. http://dx.doi.org/10.1016/j.molcatb.2015.07.012

[24] Rao, A.B., Reddy, G.R., Prasad, E., Sridhar, S. and Ravikumar, Y.V.L. (2012) An Improvised Process of Isolation, Purification of Steviosides from Stevia rebaudiana Bertoni Leaves and Its Biological Activity. International Journal of Food Science and Technology, 47, 2554-2560. http://dx.doi.org/10.1111/j.1365-2621.2012.03134.X

[25] Rao, A.B., Prasad, E., Roopa, G., Sridhar, S. and Ravikumar, Y.V.L. (2012) Simple Extraction and Membrane Purification Process in Isolation of Steviosides with Improved Organoleptic Activity. Advances in Bioscience and Biotech- 
nology, 3, 327-335. http://dx.doi.org/10.4236/abb.2012.34048

[26] Liu, J., Li, J.W. and Tang, J. (2010) Ultrasonically Assisted Extraction of Total Carbohydrates from Stevia rebaudiana Bertoni and Identification of Extracts. Food and Bioproducts Processing, 88, 215-221. http://dx.doi.org/10.1016/j.fbp.2009.12.005

[27] Ladisch, M.R., Lin, K.W., Voloch, M. and Tsao, G.T. (1983) Process Considerations in the Enzymatic Hydrolysis of Biomass. Enzyme and Microbial Technology, 5, 82-102. http://dx.doi.org/10.1016/0141-0229(83)90042-X 


\section{Supplementary Data}

\section{Experimental data:}

The spectral data of isolated Stevioside: m.p $197^{\circ} \mathrm{C}-199^{\circ} \mathrm{C}$; LC-MS (m/z) $803(\mathrm{M}-\mathrm{H}): 839(\mathrm{M}-\mathrm{Na})$; $[\alpha]_{\mathrm{D}}-9.92$ $\left(\mathrm{H}_{2} \mathrm{O}\right.$, c 3.0; std. stevioside $[\alpha]_{\mathrm{D}}-27.3\left(\mathrm{H}_{2} \mathrm{O}\right.$, c 3.0); IR $(\mathrm{KBr}): 3388,2937,1739,1658,1458,1372,1075,892$ $\mathrm{cm}^{-1}$; ${ }^{1} \mathrm{HNMR}\left(300 \mathrm{MHz}, \mathrm{C}_{5} \mathrm{D}_{5} \mathrm{~N}\right): \delta 0.9$ (d, J = $\left.13.4 \mathrm{~Hz}, \mathrm{C}_{1}-\mathrm{H}\right), 2.22\left(\mathrm{~s}, 2 \mathrm{H}, \mathrm{C}_{2}-\mathrm{H}\right), 1.03\left(\mathrm{~d}, \mathrm{~J}=11.70 \mathrm{~Hz}, \mathrm{C}_{3}-\mathrm{H}\right)$, 1.05 (d, J = $\left.12.4 \mathrm{~Hz}, \mathrm{C}_{5}-\mathrm{H}\right), 2.46$ (d, J = $\left.12 \mathrm{~Hz}, \mathrm{C}_{6}-\mathrm{H}\right), 1.30$ (s, 2H, C $\left.-\mathrm{H}\right), 0.88$ (s, 1H, C9-H), 5.13 (d, J = 7.55 $\left.\mathrm{Hz}, \mathrm{C}_{11}-\mathrm{H}\right), 2.25$ (s, 2H, C $\left.12-\mathrm{H}\right), 2.71$ (d, J = $\left.11.8 \mathrm{~Hz}, \mathrm{C}_{14}-2 \mathrm{H}\right), 2.05$ (s, 2H, C $\left.15-\mathrm{H}\right), 5.3\left(\mathrm{~d}, \mathrm{~J}=7.5 \mathrm{~Hz}, \mathrm{C}_{17}-2 \mathrm{H}\right)$, 1.25 (s, 3H, $\left.\mathrm{C}_{18}-\mathrm{H}\right)$.

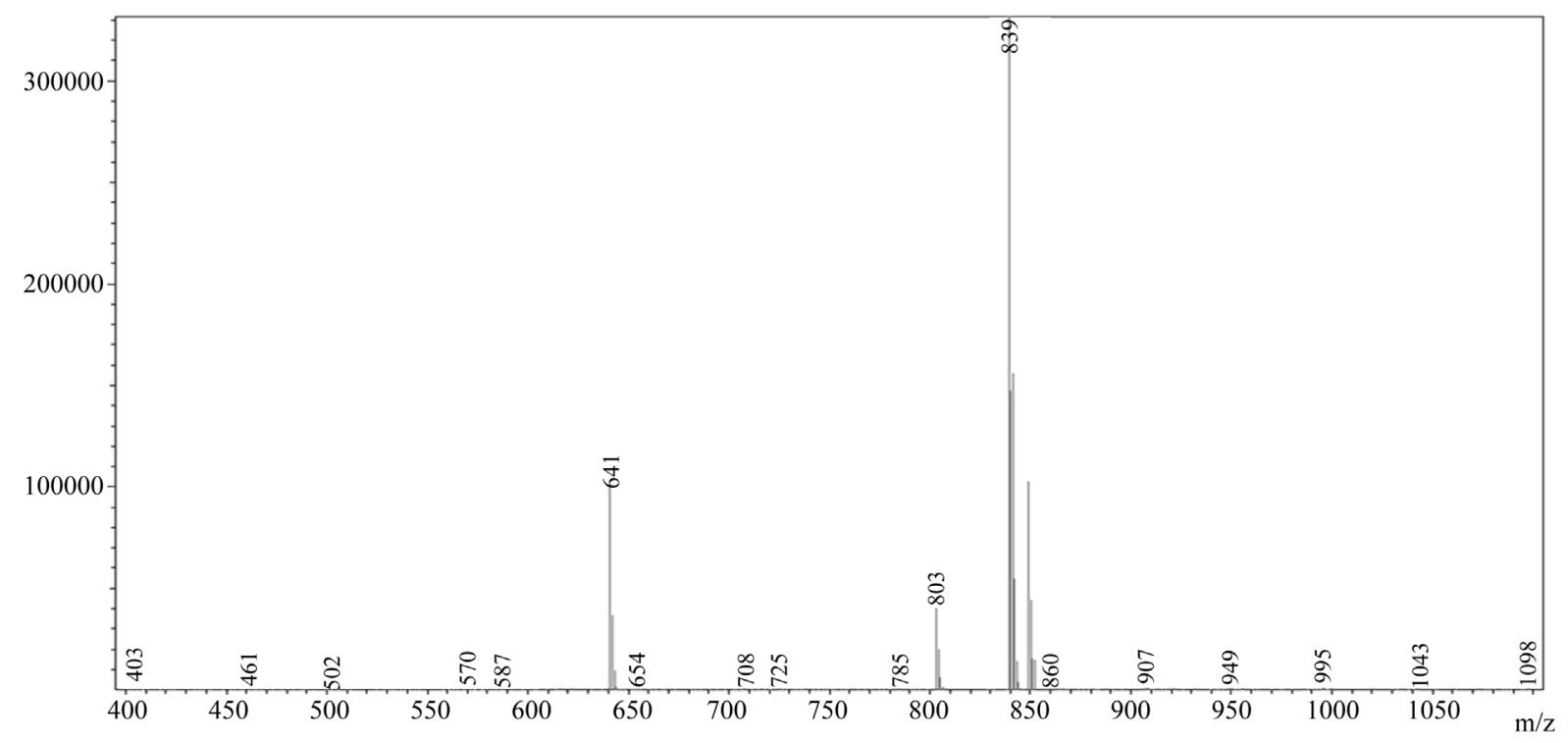

Figure 4. LC-MS spectrum of standard stevioside hydrate.

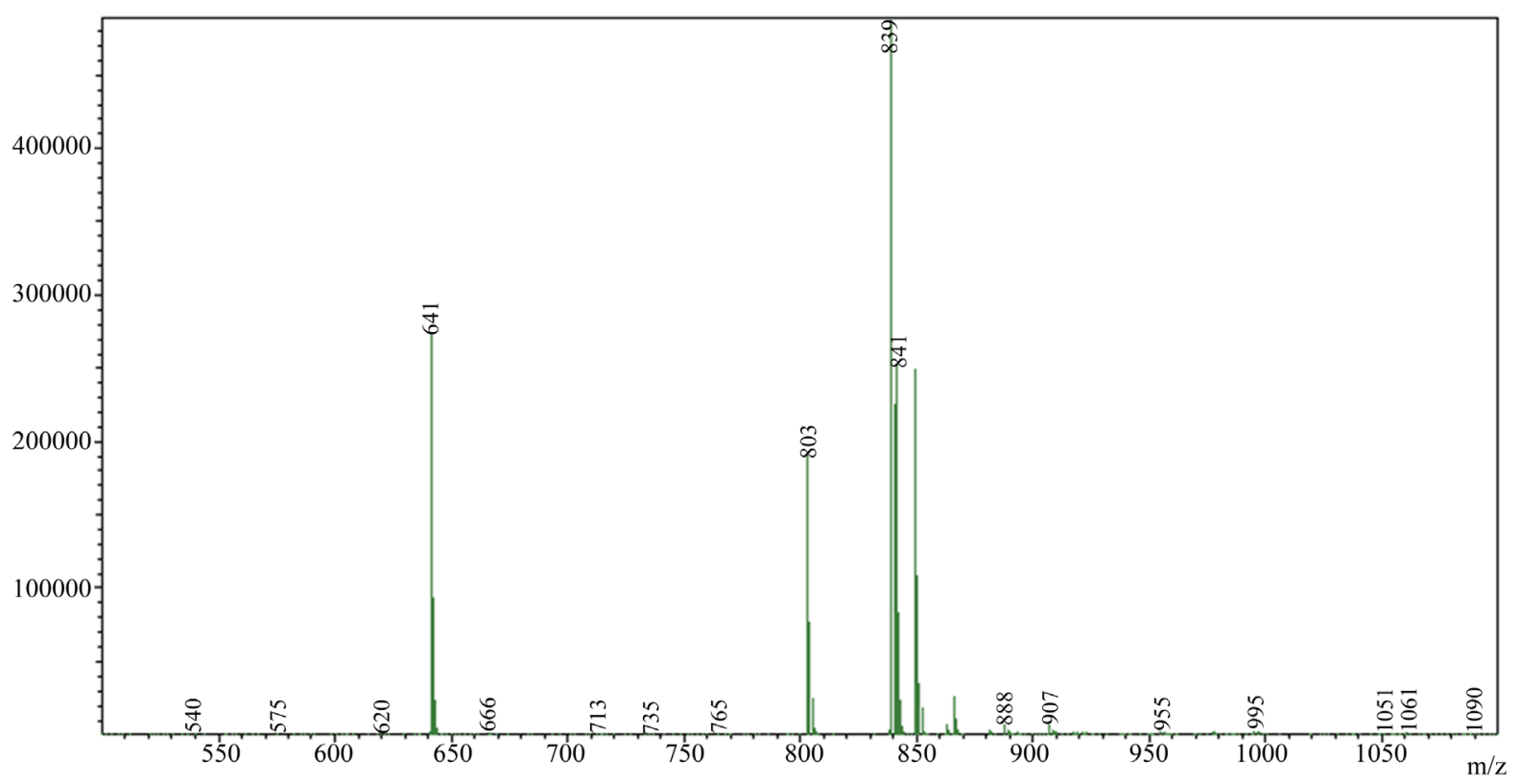

Figure 5. LC-MS spectrum of extracted stevioside. 


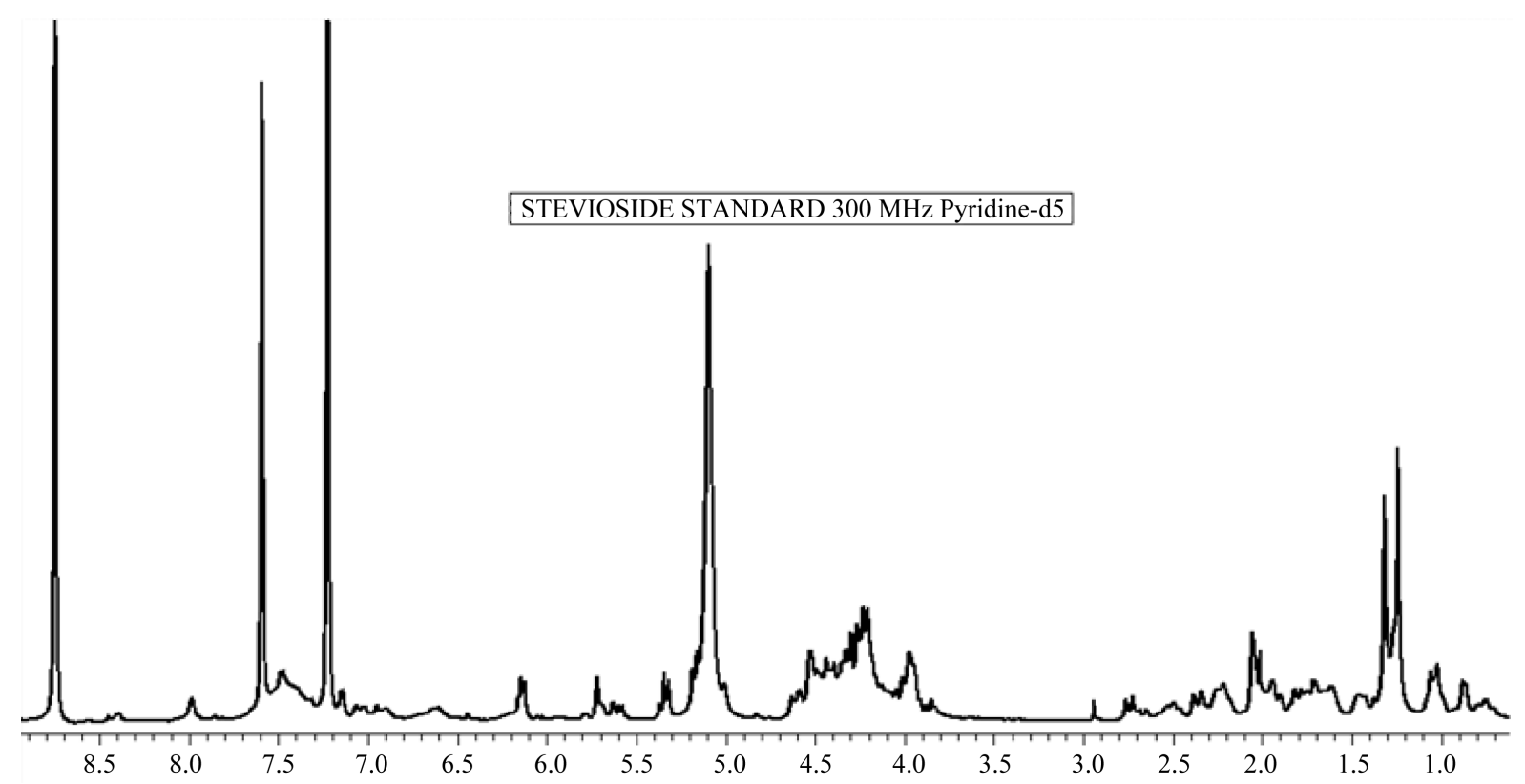

Figure 6. ${ }^{1} \mathrm{H}-\mathrm{NMR}$ spectrum of standard stevioside.

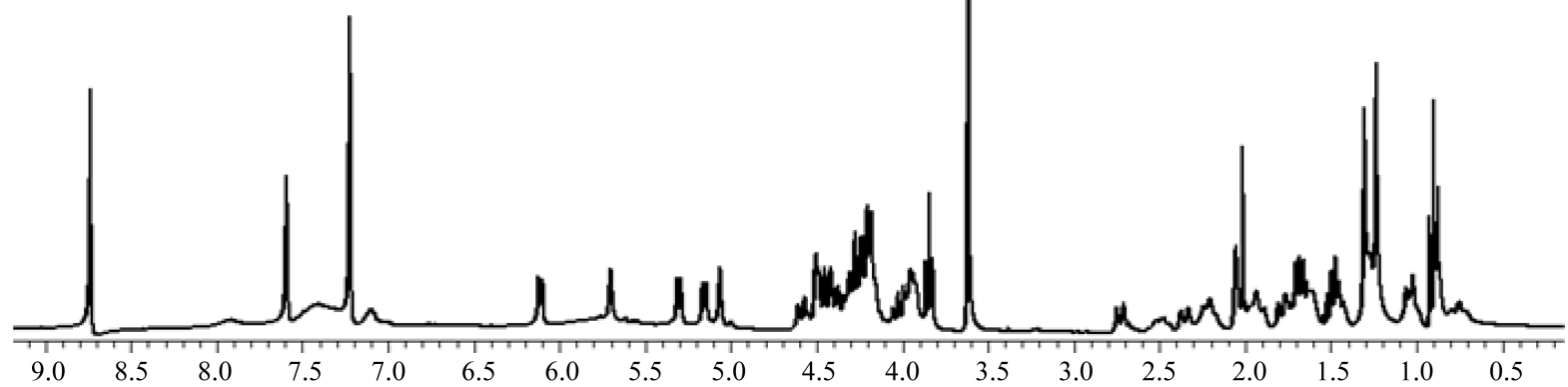

Figure 7. ${ }^{1} \mathrm{H}$-NMR spectrum of extracted stevioside. 


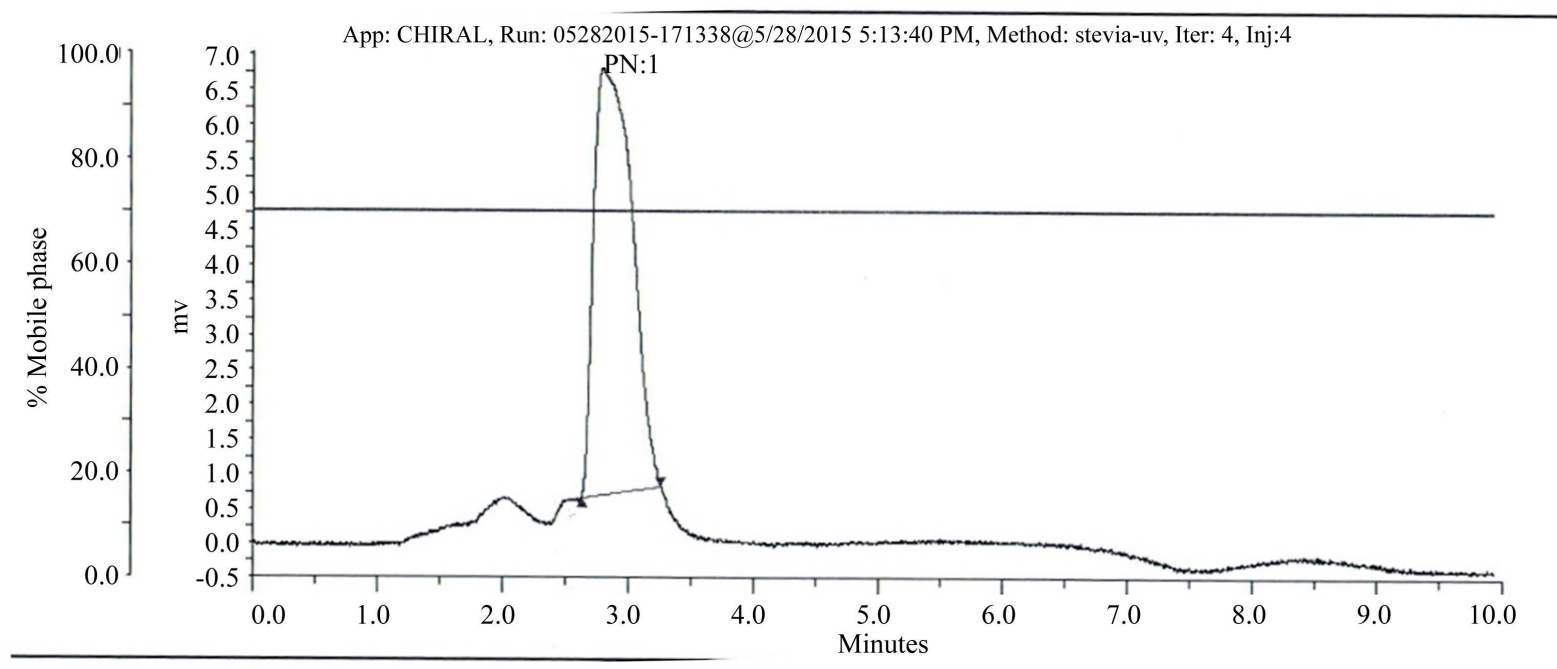

Figure 8. HPLC chromatogram of standard stevioside hydrate.

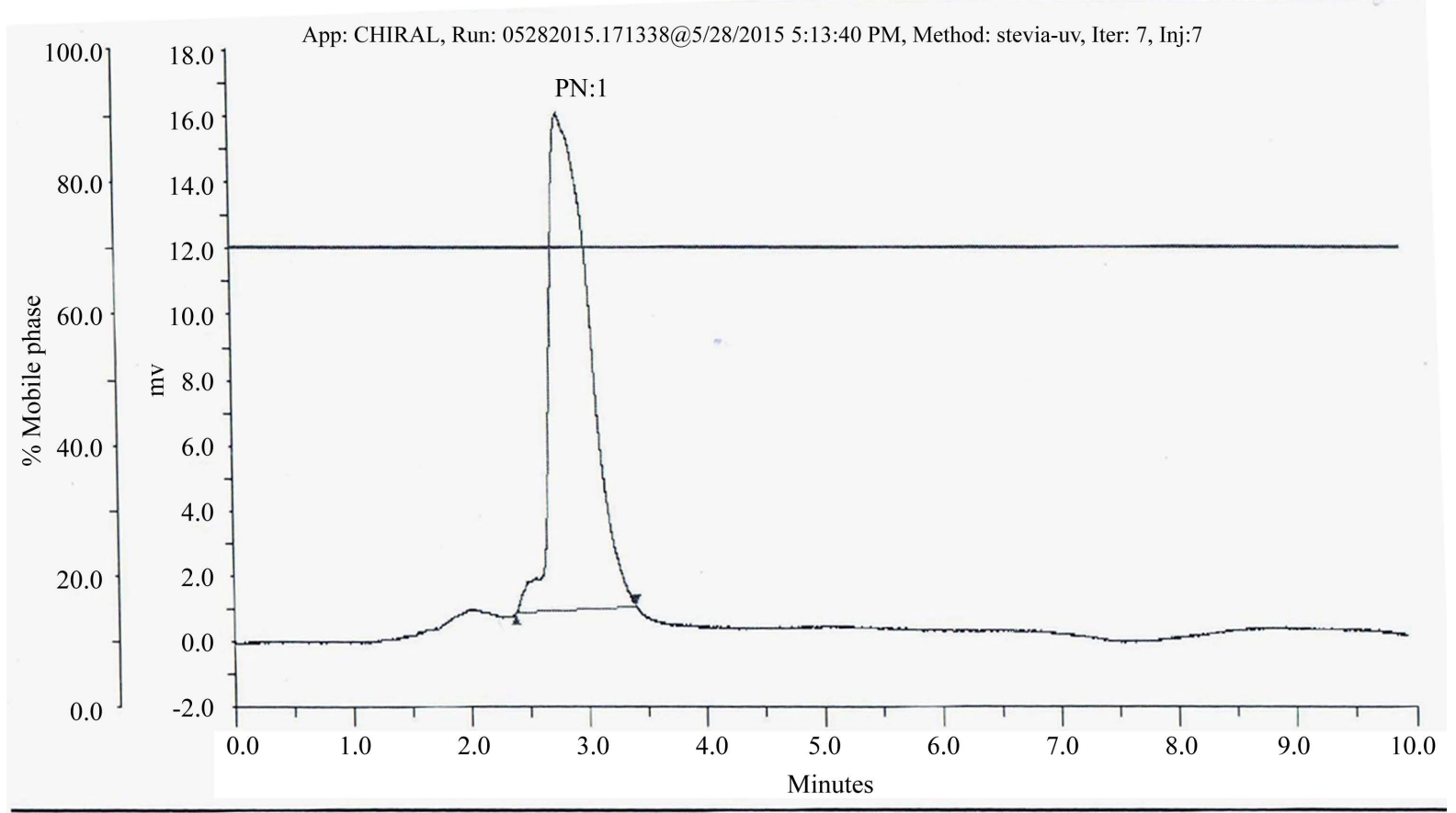

Figure 9. HPLC chromatogram of extracted stevioside. 